\title{
A Newly Emerging Disease of Papaya in Ethiopia: Black Spot (Asperisporium caricae) Disease and Management Options
}

\author{
Endriyas Gabrekiristos ${ }^{*}$, Asmare Dagnew
}

Ethiopian Institute of Agricultural Research, Melkassa Agricultural Research Center, P.O. BOX 436, Adama, Ethiopia

\begin{abstract}
Papaya (Carica papaya L.) is an important fruit crop which is cultivated widely for consumption as a fresh fruit and for use in drinks, jams, candies and as dried and crystallized fruit. It has high nutritive and medicinal value. Papaya is also used as a source of cash-income. Production of papaya in Ethiopia is increasing through time; yet the average production and export is very low due to various abiotic and biotic factors. Among which, diseases cause much of the damage. Papaya is attacked by several diseases like, anthracnose, powdery mildew, black spot and papaya ring spot. Among the emerging diseases of papaya in Ethiopia, black spot disease caused by Asperisporium caricae is the most lethal by causing disease on photosynthetic and economic (fruit) plant parts. The fruits are affected on the surface, reducing the fresh-market value. In Ethiopia, Asperisporium caricae has been observed in most papaya producing areas. However, the severity of the pathogen has not been well profiled. The pathogen was not also characterized, which is the base to device management options. Currently, the use of fungicides and resistant cultivars are the preferred management options. This disease is found to be serious in the recent past few years by causing substantial economic loss. Therefore, the aim of this paper is to review the newly emerging black spot disease of papaya, its distribution and management options.
\end{abstract}

Keywords: Black spot disease; Economic importance; Pathogen characterization; Distribution; Management and Papaya

\section{INTRODUCTION}

Papaya (Carica papaya L.) is an important fruit crop, which belongs to the family Caricaceae and cultivated widely for consumption as a fresh fruit and for use in drinks, jams, candies and as dried and crystallized fruit [1]. The fruits have great nutritional value and contain protein, fat, carbohydrates, calories and also as a source of calcium, iron, sodium, potassium, $\beta$-carotene, vitamin B2, niacin and vitamin C [2].

The leading global producers of papaya are; India, Brazil, Nigeria, Indonesia, Mexico, Dominican Republic, Democratic Republic of Congo, Philippines, Venezuela and Thailand [3]. Papaya has gained more importance owing to its high palatability, early fruiting, highest productivity per unit area, multifarious uses like food, medicine and industrial input. Papaya is one of the common fruits grown in Ethiopia and is commercially cultivated in about 3484.46 ha of land with annual production of about 54,355.024 tons [4].

However, papaya suffers a great loss due to various biotic factors. In Ethiopia, diseases such as anthracnose (Colletotrichum gloeosporioides), Phytophthora (Phytophthora palmivora), powdery mildew, black spot (A. caricae) and papaya ring spot virus are seriously affecting the production and productivity of papaya $[5,6]$. Among the emerging diseases of papaya, black spot disease caused by A. caricae is the most lethal. Both leaves and fruits of papaya can be affected by the black spot disease. In the early days, development of black spots on the leaves and the fruits of papaya due to infection were reported in Florida [7]. It is also one of the most serious fungal diseases of papaya in Brazil, where papayas are continuously grown throughout the year in a climate conducive to outbreaks of severe epidemics [8]. In addition, it causes the reduction of photosynthetic area; and

"Correspondence to: Endriyas Gabrekiristos, Ethiopian Institute of Agricultural Research, Melkassa Agricultural Research Center, P.O. BOX 436, Adama, Ethiopia, Tel: +251-916000330; E-mail endriasgabre@gmal.com

Received: November 25, 2019; Accepted: February 10, 2020; Published: February 17, 2020

Citation: Gabr ekiristos E, Dagnew A (2020) A N ewly Emerging Disease of Papa ya in Ethiopia: Black Spot (Asperisporium caricae) Disease and Management Options. J Plant Pathol Microbiol 11: 488. doi: 10.35248/ 2157-7471.20.11.488

Copyright: () 2020 Gabrekiristos E, et al. This is an open-access article distributed under the terms of the Creative Commons Attribution License, which permits unrestricted use, distribution, and reproduction in any medium, provided the original author and source are credited. 
hence the pathogen can affect commercial value of the fruits [9]. The then Ethiopian Agricultural Research Organization [5] gave low priority to the pathogen, which is now becoming emerging disease throughout the production areas in Ethiopia. Therefore, this paper highlights the current status, distribution and management options of black spot disease of papaya in Ethiopia.

\section{RESEARCH METHODS}

\section{Nutritive and economic importance of papaya}

The center of origin of papaya is South Mexico to the Andes in South America [10]. Papaya is known for its source of ascorbic acid, carotene, riboflavin and a fair source of iron, calcium, thiamin, niacin, pantothenic acid, vitamin B6 and K [11]. It has also been reported as good source of vitamin A, vitamin C, calcium; and it has high nutritive and medicinal values [12]. The raw fruits contain alkaloid or proteolytic enzyme called "Papain", which is a commercial product of several tropical American nations and is used in several medicines and food preparations [13]. The digestive enzyme, Papain, is used as an industrial ingredient in brewing, meat tenderizing, pharmaceuticals, beauty products and cosmetics [13]. The fruits have tremendous nutritional value and contain $1.5 \%$ protein, $0.1 \%$ fat, $7.1 \%$ carbohydrates, and 35.0 calories per 100 g edible fruit. Fruits also contain high levels of calcium, iron, sodium, potassium, $\beta$-carotene, vitamin B2, niacin and vitamin $C$ [2].

The top five papaya producing countries in the world are India (5.6 million tons), Brazil (1.6 million tons), Indonesia $(840,121$ tons), Nigeria (850,000 tons) and Mexico (836,370 tons) [3]. The productivity of papaya in Ethiopia is 54,355.0 tons on 3484.5 ha (Figure 1) of land, which is very low as compared with the world average production [14]. Even though the production trend is increasing through time, comparing to the top papaya producers, Ethiopia has not given due attention to this valuable fruit which can brought cash income from export market and ranked 23rd [14]. Since the agro-ecology is quite important to papaya production, Ethiopia has the capacity to industrialize the production system to become one of the top papaya producer and exporter countries in the world.

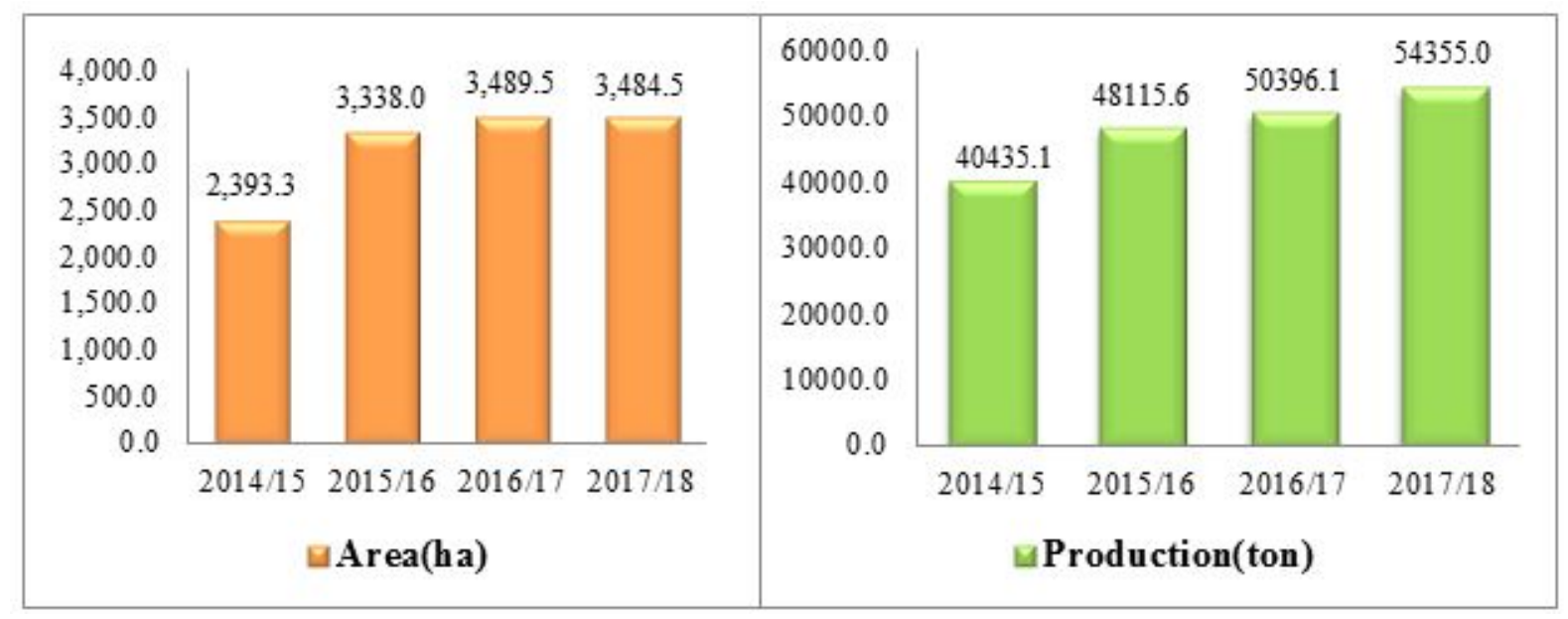

Figure 1: The status of papaya in area coverage and total production trend from 2014 to 2018 in Ethiopia.

\section{Distribution and economic importance of black spot disease of papaya}

Black spot diseases of papaya, caused by A. caricae, is a wide spread fungus disease found in many countries such as the USA, Brazil, South Africa, China, Philippines, Sri Lanka and Taiwan $[15,16]$. In India, the disease was observed as early as 1977 on the papaya variety Coorg Honey Dew at Chettali, Karnataka, and in Palani hills on Variety Co 1 during cooler months [17], and in Chittor of Andhra Pradesh [18]. Recently, the black leaf spot disease of papaya was reported to be a widespread disease in major papaya growing regions of Tamil Nadu in almost all the commercially grown varieties; and the disease incidence ranged from 10.0 to 23.8 percent disease index (PDI). If the disease is not controlled at early stage, leaf function will be damaged and defoliation can occur, thereby reduces fruit sugar content and quality.

Black spot is one of the fungal diseases that have expressive consequences in terms of photosynthetic area and recurring damages to production and papaya fruit quality [19-22]. The pathogen affects the leaf and fruit parts which get attention by producers and consumers in reducing the economic value. The tissue beneath the lesions remains firm, but the value of harvested fruit with these symptoms is reduced [23]. Hence, further studies on the epidemiology of this disease with respect to spread, survival, and alternate hosts are required to device strategic management options.

In Ethiopia, the area occupied by papaya is increasing through time and the production is also simultaneously increasing [4]. However, among the various factors responsible for low yield of papaya, diseases play a vital role. In the country, different diseases have been recorded on papaya [4], of them; anthracnose, root rot (Phytophthora p.), black spot and dieback are becoming important. Among the reported diseases of papaya, black spot has been emerging as economically important disease to major papaya producing areas, majorly in the Central rift valley of Ethiopia [5]. 


\section{Morphological characteristics of the causal agent}

The fungus on the infected papaya leaves was identified as A. caricae by comparing with the description and illustrations given by [24]. Sporulation of A. caricae was hypophyllous, ranging from dark blackish brown to black. Stroma was well developed, and erumpent (Figure 2). Conidiophores were olivaceous brown, geniculate, smooth in dense fascicles with several prominent conidial scars at the tip up to $52 \mu \mathrm{m}$ long $\times 6-9 \mu \mathrm{m}$ wide [25]. Conidiogenous is cells polyblastic with thickened and darkened scars. Conidia solitary, ellipsoidal, pyriform or clavate, 1-septate (mature), hyaline to mid pale brown, verrucose, 16-32 $\times 5-11 \mu \mathrm{m}$. Conidia are elliptic-oviod, rounded at the top, one or two septate, hyaline to brown in colour. Size of the conidia varies from $27-30 \mu \mathrm{m} \mathrm{[26].}$

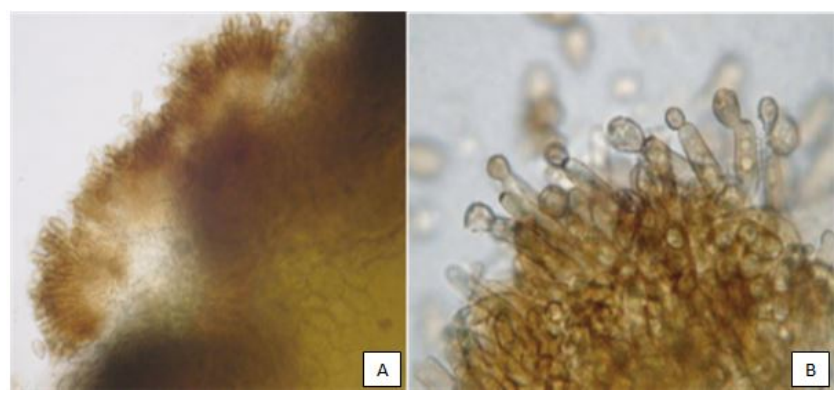

Figure 2: Asperisporium caricae on carica papaya: (A) Stromata and (B) Conidiophores.

Sporodochia of A. caricae was hypophyllous, dark blackish brown to black, stroma well-developed, erumpent. Conidiophores closely packed together and covering the surface of the stroma, usually unbranched, hyaline to olivaceous brown, with several prominent conidial scars at the apex, up to $45 \times 69$ $\mu \mathrm{m}$. Conidia solitary, ellipsoidal, pyriform or clavate, 1-septate, hyaline to mid pale brown, verrucose, 14-26 × 7-10 $\mu \mathrm{m}[25,27]$.

\section{Host range, epidemiology and symptom of papaya black spot}

Black Spot disease of papaya is caused by the fungus A. caricae and papaya is the only known host of this pathogen [28,29]. The initial symptoms of black spot caused by A. caricae are small, water-soaked spots which are developed on the reverse side of the young leaves, later become greyish-white (Figure 3a) and finely black pustules (black conidial masses) are formed (Figures 3b-3d). Affected leaves become necrotic, weak and subsequently die under severe disease pressure, which results in extensive defoliation. Black spot disease of papaya is very lethal and thus both leaves and fruits of papaya can be affected [30]. Severe black spot infections can cause the leaves to curl and die prematurely which affects photosynthesis. The pathogen can cause direct damage by causing spots on the fruit. Therefore, management of this disease is very important [30].
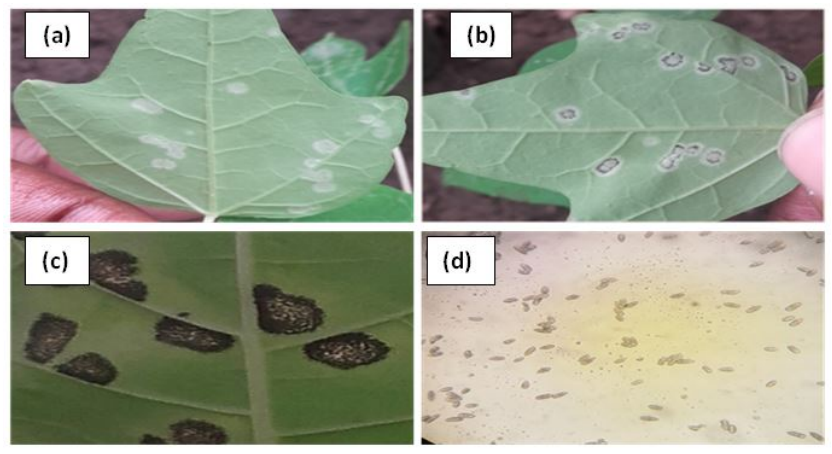

Figure 3: (a-c) Sign of black spot of papaya; and (d) conidia.

Symptoms initiated during cooler weather accompanied with rains, and the disease spread continued even after rains. Periods of wet weather may increase the development of the disease [13]. There was a marked correlation between the severity of $\mathrm{A}$. spotting and the rainfall where spotting increased considerably with increased in rainfall while during dry spells the disease declined markedly [7,31,32]. During prolonged dry weather condition, most infected trees recovered completely from the disease.

\section{MANAGEMENT OPTIONS}

\section{Cultural management}

Removal of leaves and fruits with symptoms of black spot disease from the orchard reduces the initial inoculum [33]. Similarly, infected old leaves hanging from trees should be removed carefully to reduce the number of spores that spread the disease [34]. Removal of infected leaves will increase air circulation and improve spray penetration through the fruit column [32]. Heavily infected leaf blades should be removed by cutting the petiole half way between the leaf blade and the trunk to protect insects and pathogens to enter the wound [35]. Wind protection around plantings is important to minimize fruit abrasions which can create an entry for pathogens [34]. Scouting the orchard periodically is very important to decrease infestation level by weeds, reduce the suffocation of the orchard, and fertilize the plantation.

\section{Host resistance}

Genetic resistance has emerged as a promising and sustainable control alternative for black spot disease of papaya [35]. It is essential to be aware of the genetic variability of papaya genotypes to set plans for improvement strategies [36,37]. Evaluated 41 papaya genotypes against black spot and the genotypes that showed better resistance were lines $1,4,9$, and 19 [37]. Lines 4 and 9, and the parent 'SEKATI' generated the best results in all the variables assessed [37]. Accordingly, the use of genetic parameter estimates is relevant to show the variability of genetic materials [38,39]. In Ethiopia, black spot disease of papaya was reported 19 years back [5] and now a day the pathogen is wide spread due to its nature. However, there has no effort made on identifying resistant papaya varieties and lines to black spot pathogen, which is an emerging disease. 


\section{Chemical control method/fungicide}

Application of protective or systemic fungicides when the first symptoms appear is the best option to early manage black spot disease of papaya [33]. In Brazil, fungicides are used to control this disease for all papaya plantations produced commercially [40]. It is also reported that high black spot pressure influence the efficacy of mancozeb and tebuconazole fungicides [23]. Therefore, options of curative and protectant fungicides should be availed to control such economically important pathogen. In this regard, laboratory tests showed that A. caricae was more sensitive to difenoconazole than tebuconazole [41]. Similarly it was reported that, Difenoconazole, Pyraclostrobin and Chlorothalonil were better in managing papaya black spot than Mancozeb and Tebuconazole [13]. Fungicides viz., Difenoconazole, Chlorothalonil, Propiconazole and Hexaconazole were very effective in managing this pathogen [30]. It is advisable to look for signs of disease on the new growth since the fungicides protect the new leaves and fruits; but old damage cannot be undone [34,42].

\section{DISCUSSION AND CONCLUSION}

Papaya is an important fruit crop which is cultivated widely for consumption as a fresh fruit and for use in drinks, jams, candies and as dried and crystallized fruit. The fruits have tremendous nutritional value and contain protein, fat, carbohydrates, calcium, iron, sodium, potassium, $\beta$-carotene, vitamin B2, niacin and vitamin C. papaya is the common fruit grown in Ethiopia and is commercially cultivated in about 3484.46 ha of land and producing 54,355.024 t/year.

Papaya seriously suffers a great loss due to diseases such as anthracnose (C. gloeosporioides), Phytophthora (P. palmivora), black spot (A. caricae) and papaya ring spot virus. In Ethiopia, among the emerging diseases of papaya, black spot disease caused by A. caricae is most lethal and causes reduction of photosynthetic area. The pathogen damages the fruit quality which results in reduction of marketable value of the fruits. Black spot of papaya is widely distributed in major papaya growing areas of Ethiopia.

In conclusion, a specific month at which the pathogen becomes aggressive should be identified and documented for papaya producers. Based on the schedule (identified month) it is possible to forecast for the coming season. In Ethiopia, the pathogen has not been characterized so far. Therefore, as a research gap, basic studies on morphological identification should be conducted to characterize isolates. Screening of papaya germplasm should also be intensively conducted to identify tolerant/resistant papaya genotype. Country wide epidemiological survey is also important, since the pathogen outbreaks prefer a specific season which is used to devise management options for early mitigation.

\section{REFERENCES}

1. Villegas VN. Edible fruits and nuts - Carica papaya L. In EWM Verheij, RE Coronel, (Eds), Volume 2. Wageningen University, The Netherlands. 1997;12.
2. Samson JA. Tropical fruits. (2nd edn). Longman Scientific and Technical. 1986;256-269.

3. https://www.mapsofworld.com/world-top-ten/papaya-producingcountries.html

4. Central Statistical Agency Agricultural Sample Survey. The federal democratic republic of Ethiopia, Meher Season (2017/2018). 2018.

5. Ethiopian Agricultural Research Organization. Annual report. Ethiopian Agricultural Research Organization. EARO, Addis Ababa, Ethuiopia. 2001.

6. Mohammed Y, Wondirad M, Eshetu A, Girma A, Dereje T, Temam H, et al. Review of Research on fruit crop diseases in Ethiopia. Increasing crop production through improved plant protection volume II. 2009;231-251

7. Stevens J. Papaw diseases. Proceedings Florlda Horticultural Society. 1939;52: 57-63.

8. Ventura JA, Costa H, Tatagiba JS. Manejo das Doencas do Mamoeiro. In: A Cultura do Mamoeiro: Tecnologias de Producao, Martins, DS and AFS. Costa (Eds). Incaper, Vitoria, Spain. 2003;231-308.

9. Ventura JÁ, Rezende JAM. Doenças do Mamoeiro. In: Amorim L, Bergamim Filho A, Camargo LFA, Rezende JAM. Manual de Fitopatologia: Doenças das plantas cultivadas. Agr. Ceres. Sao Paulo. 2016.

10. Mishra P, Gaur R. Current knowledge of viruses infecting papaya and their transgenic management. Plant viruses: Evolution and management. 2016;11:189-203.

11. Arriola MC, Calzada JF, Menchu JF, Role C, Garcia R. Papaya In : Tropical and sub-tropical fruits, Nagy $\mathrm{S}$ and Shaw PE. (Eds). 1980;316-340.

12. https://archive.org/details/in.ernet.dli.2015.271151/mode/2up

13. Shantamma SG, Rangaswamy KT, Bheemanagouda HP. Management of black spot of papaya caused by Asperisporium caricae. International Journal of Plant Protection. 2014;7:212-216.

14. Central Statistical Agency Agricultural sample survey. The federal democratic republic of Ethiopia (SeptemberDecember), 2014/2015. 2015.

15. Desmond YO, Ronald AH. Black spot of papaya disease Asperisporium caricae (Speg.) Maulbl. State of Hawaii New Pest Advisory no. 2001-01. Department of Agriculture. 2001.

16. https://www.eppo.int/resources/eppo_databases/global_database

17. Ullasa BA, Sohi HS, Rao NNR. Occurrence of Asperisporium leaf spot of Papaya in India. CurrentScience. 1978;47: 233-234.

18. Reddi KM, Giridhara KT, Raja RK. Survey and prevalence of Asperisporium caricae, Incitant of black leaf spot of papaya and evaluation of certain new fungicidal. International Journal of Research Studies in Agricultural Sciences. 2015;4:10-14.

19. Oliveira AAR, Barbosa CJ, Santos HP, Meissner PE. Doenças e seucontrole. In: Trindade AV (Org.). Mamãoprodução: aspectostécnicos. Cruz das Almas: Embrapa Mandioca e Fruticultura. (Frutas do Brasil, 3). Brasília, Distrito Federal. 2000;43-52.

20. Martelleto LAP, Ribeiro RLD, Carmo MGF, Martelleto MS. Incidência da varíola, causada por Asperisporium caricae, emfolhas de mamoeiros submetido saomanejoorgânicoemdiferentesambientes de cultivo. Summa Phytopathol. 2009;35:288-292.

21. Cooke T, Persley D, House S. Diseases of Fruit Crops in Australia, CSIRO. 2009;1-288.

22. Souza MG, Pereira JCR, Garcia MVB, Kano C, Brioso PST. Primeirorelato de pinta-preta, causada por Asperisporium caricae, emmamoeiro no Amazonas. Comunicado Técnico. 2014;9. 
23. Peterson RA, Grice KRE. Papaw disease management. Final Report, Horticultural Research \& Development Corporation. 1999, 1-45.

24. Liberato JR, Shivas RG. Asperisporium black spot of papaya (Asperisporium caricae) Pest and Diseases Image Library. 2006.

25. Ilis MB, Holliday P. Asperisporium caricae, CMI Descriptions of Pathogenic Fungi and Bacteria. 1972;347:1-2.

26. Shantamma, Mantur SG. Mysore Journal of Agricultural Sciences. 2014;48:56-60

27. Maublanc A. Disease of the leaves of papaya (Carica papaya). Socitey Mycologique de France. 1913;29:353-358.

28. Cumagun A, Padilla CL. First record of Asperisporium caricae causing black spot of papaya in the Philippines. Csiro Publishers. 2007; 2:89-90.

29. https://hdoa.hawaii.gov/pi/files/2013/01/npa01-01_blkspot.pdf

30. Shantamma SG, Mantur SC, Chandra SK, Rangaswamy T, Bheemanagouda P. Status of black spot of papaya (Asperisporium caricae): A New Emerging Disease. Int. J. Curr. Microbiol App Sci. 2018; 7:309-314.

31. Adikaram and Wijepala. Asperisporium Black Spot in Carica Papaya: A New J Natn Sci Coun Sri Lanka. 1995; 23: 213-219

32. Constantinides LN, McHugh JJ. Workshop Summary: Pest Management Strategic Plan for Papaya Production in Hawai'i. Komohana Research Extension Center. University of Hawai'i at Manoa. 2005.

33. Suzuki MS, Zambolim L, Liberato JR. Progresso de doenças fúngicas e correlação com variáve is climáticas emmamoeiro. Summa Phytopathological, Botucatu. 2017;33:167-177.

34. Jari SK, Randall TH, Michael K, Steven F, Maria DC, Stuart T, et al. Best Management practices for Asperisporium Black Spot of Papaya. 2011.
35. Vivas M, Silveira SF, Viana AP, Amaral Jr AT, Ferreguetti GA, et al. Resistance to multiple foliar diseases in papaya genotypes in Brazil. Crop Protection. 2015;71: 138-143.

36. Vivas M, Ramos HCC, Santos PHD, Silveira SF, Pereira TNS, Amaral Jr. AT, et al. Heterosis and genetic diversity for selection of papaya hybrids for resistance to black spot and phoma spot. Trop Plant Pathol. 2016;41:380-389.

37. Poltronieri TP, Silveira SF, Vivas M, Santa CR, Cortes DF, Azevedo AO. Selecting black-spot resistant papaya genotypes derived from backcrossing and hybrids. Genetics and Molecular Research. 2017;16: 16019401

38. Cardoso DL, Silva RF, Pereira MG, Viana AP. Diversidadegenética e parâmetrosgenéticosrelacionados à qualidadefisiológica de sementesemgermoplasma de mamoeiro. Rev Ceres. 2009;56:572-579

39. Vivas M, Silveira SF, Vivas JMS, Santos PHD, Carvalho BM, Daher RF, et al. Phenotypic characterization of papaya genotypes for powdery mildew resistance. Crop Breed Appl Biotechnol. 2017;17:198-205

40. Ferreira LT, Avidos MFD. Transgenic papaya reaches the field, an interview with Manoel Souza. In: Biotechnologiz Ciencia \& Desenvolvimento. 1999.

41. Vawdrey LL, Grice KRE, Westerhuis D. Field and laboratory evaluation of fungicides for the control of brown spot (Corynespora cassaiicola) and black spot (Asperisporium caricae) of papaya in north Queensland, Australia. Australian Pl. Pathol. 2008; 37 : 552-558.

42. Thiribhuvanamala A, Karthikeyan P, Reddy K, Soorianatha S (2016) Prevalence of black leaf spot of papaya caused by Asperisporium caricae in Tamil Nadu, India. Pest Management in Horticultural Ecosystems. 2016;22:193-194. 